\title{
Women and Inheritance Rights in Manggarai, Eastern Indonesia: A Fight for Gender Equality
}

\author{
Yohanes S. Lon ${ }^{1}$, Fransiska Widyawati ${ }^{2}$ \\ \{yohservatiusboylon@gmail.com ${ }^{1}$, fwidyawati10@gmail.com ${ }^{2}$ \} \\ ${ }^{12}$ Universitas Katolik Indonesia Santu Paulus Ruteng, Nusa Tenggara Timur, Indonesia
}

\begin{abstract}
This paper explores the custom of inheritance in Manggarai, Eastern Indonesia. Women in this community are vulnerable to unfair treatments due to the lack of support for women's rights. This phenomenon is aggravated by men's sense of entitlement and materialism. This studiy aims at analizing how inheritance is practiced today and whether there are changes in people's perception on women's inheritance rights and if so, what factors are responsible for such changes. It uses both quantitative and qualitative approach. This study has discovered that gender inequality is still inevitable in the inheritance custom in Manggarai due to a strong patriarchal ideology. This paper serves as a reminder that gender awareness is still uncommon in many communities in Asia including in Indonesia; hence, there is a need for greater spread of awareness about gender equality. Improvements in education, career opportunities, and economic status for women can potentially be the catalyst of change in perception of people in a patriarchal community.
\end{abstract}

Keywords- Inheritance rights, Manggarai, Eastern Indonesia, women's right gender

\section{Introduction}

Contemporary studies about inheritance for women have been receiving attention from scholars all over the world. The United Nations [1] [2] has also shown interest in this matter as inheritance can lead to the betterment of women's lives, eventually forming a fair and just society. Inheritance for women improves their economy (Carter \& Barrett, 2006) [4]. It allows women to spend for themselves, their children, and on education resulting also in better nutrition and health. Inheritance also saves women from economic vulnerability, narrows the poverty gap, and empowers women [5] [6]. The study by [7] views inheritance for women as a significant model of property transfer in society. Inheritance for women not only affects their personal lives, but also provides confidence which leads women to better access in social, economic, and political aspects of their lives.

Despite the known benefits of inheritance for women and society, many studies show that women are still vulnerable and are subjected to inequality in inheritance rights. In India, despite gender-progressive reforms to its inheritance law, parents still deliberately choose to disinherit their daughters (Roy, 2015: 233-251) [9]. In other East Asian nations such as Japan, South Korea, and Taiwan, patriarchy remains a dominant force affecting inheritance rights despite 
changes in the family structure during the last century [10]. In China, despite changes in the family structure which have led to changing perception on gender from generation to generation $(\mathrm{Hu} \& \mathrm{Scott}, 2014$ : 1267-1293), the preference for a son over a daughterespecially in the context of one-child policy-affects the management of family inheritance [10] [11]. In Indonesia, women have limited rights over family inheritance, especially stepdaughters and second wives [10] (Butt, 2012: 196-198). In Arab, women are excluded from inheritance rights even though gender equality constitutes a major dimension of basic family law [13]. In Israel, gender discrimination in inheritance rights is still prevalent due to the practice of patriarchy [14]. These studies show that in many parts of the world where patriarchy prevails, women remain a vulnerable group within their family and community, including in their inheritance rights. These studies also remind us that patriarchy is not just a force of the past - it is still alive and well even in modern societies (Littrell, 2013: 310-324).

This study follows the same flow of discussion of past studies listed above. It explores how contemporary families in Manggarai, Eastern Indonesia manage inheritance matters and their perception on women's inheritance rights. According to the tradition, only sons are eligible for family inheritance as they are considered the heirs of the clan. Daughters cannot receive family inheritance as they will eventually join their husbands' clans. Whether this traditional concept is still practiced and what factors affect any changes would be the focus of this paper.

\section{Method}

This research applied qualitative approach. To collect the data, it used ethnography and in depth interview methods. Ethnography was used to understand the culture of Manggarai, in particular in regarding to inheritance system, and how man-women relation to the system.

To understand how the contemporary Manggaraian community members have practiced the inheritance in their families, this research uses in depth interview. The respondents of this study comprise of 179 families. Among them, 92 families lived in villages and 87 families lived in the town center. The respondents were chosen purposefully, whereby all families had daughter(s) (with or without sons). They also owned at least a house and a plot of land. Families living in villages tend to have more plots of land than those in town but with a lower market value.

\section{Result and Discussion}

\subsection{Men and Women in Manggaraian Culture}

Manggarai is a region in Eastern Indonesia that covers one-third of the west part of Flores Island. Manggarai people have been known for their strong in practicing their local culture [16] [17]. The majority of people are Catholics, the religion that have been supporting and maintaining the local culture as well [18] [19](Widyawati and Lon, 2019). Both, the culture and religion are very patriarchal which have influenced the practice of heritance system as this study focuses on.

Every individual in a Manggaraian family belongs to the clan. As mentioned by Nerton $(1968,353-354)$, a clan serves as a "social collectivity and socially cohesive". Every son in a Manggaraian family has a responsibility to continue his clan (Lon \& Widyawati, 2017: 14-24). As Manggarai adopts patriarchal system, father and sons hold key leadership positions in their clan. The birth of a boy is of utter importance for a clan. Families that fail to bear sons are 
viewed to be on the brink of extinction [17][22]. Traditionally, a man was allowed to remarry if his first wife failed to bear a son. This tradition was ended in the mid of the $20^{\text {th }}$ century by the advent of the Catholic Church which championed monogamy. Even though the practice of polygamy has ended, families still pressure wives to bear sons even if that means having to give birth repeatedly. Some families opt for alternatives such as adopting their relative's son. Many families feel incomplete without a son. However, we have also observed that due to economic reasons and family planning program promoted by the government, some families have given up trying to have a son. Some modern families also believe that having both a son and a daughter is a better, even though this does not correlate to equal inheritance rights, which will also be analyzed in this paper.

People in Manggarai believe in different inherent roles of a male and a female. When a boy is born, he is referred to as ata one (inside person) while a daughter is referred to as ata pe'ang (outside person). This is because a male will remain in his clan but a female will leave hers and join her husband's. As the owner and the heir of the clan, a man has many privileges. Only men can hold the positions of tu'a golo (headman), tu'a teno (chief of land), tu'a panga (head of the extended family), tu'a kilo (head of the nuclear family), tongka (speaker in marriage proposal), and tudak/torok (leader of a prayer/ritual). Men's leadership in the community and the traditional family is strengthened by the presence of the Catholic Church which also centralizes its leadership on men/priests [22]. There is a dualism in the church whereby while acknowledging the equality of men and women, it also discourages women's leadership in the church. As a result, the idea of gender equality especially in the aspect of leadership remains unfamiliar in the community despite Catholic education.

People in Manggarai also believe in traditional roles for men and women in the society, which only emphasize gender inequality. Boys are prepared to be the future leaders of the community and the breadwinner of the family, which is why they need to be masculine. On the other hand, daughters are prepared to be a wife and a mother, which is why they need to be feminine. Even though many women in modern families in Manggarai become the main breadwinner of the family, there is still an expectation for women to also take care of domestic matters even when their husbands are not working. This traditional gender concept is also happening in other parts of the world (Oakley 2016).

As ata pe'ang, a girl in Manggarai is treated as a 'guest' in her own clan before her marriage, when she would eventually belong to her husband's clan. As a result, women are never involved in decision making of family and clan matters. A contemporary study about Manggaraian women has discovered that traditional concept on women's social roles is still actively practiced today despite changes in mindset (Lon \& Widyawati, 2018). Some significant changes are owed to women's rights to education. In the past, boys were prioritized to go to school, but parents today have started to send their daughters to school as well. Arguably, this is not only due to changes in gender perception, but also due to improved family economic condition. This can be observed in families with lower income who, when faced with the option to send their son or daughter to school, would choose to send their son unless he is deemed to be unfit i.e. too naughty, dim-witted, or not willing to do so. Only then would they send their daughter to school.

In marriage, women are valued based on their fertility and ability to bear sons to be the heirs of the clan. During marriage, the groom's family must pay a sum of bride-wealth to the bride's father and brothers as the owners of the bride. This bride-wealth is also meant to strengthen the marriage and the kinship between the bride and the groom's extended families. In many cases as discovered by Lon and Widyawati (2017), the practice of bride-wealth has burdened women and caused them to feel objectified. After wedding, women are still tied to responsibility towards her family (mainly her father and brothers), which is reflected on their duty to pay for multiple rituals such as wedding and death of their brothers. However, despite this heavy monetary responsibility, women still do not have inheritance rights. 


\subsection{Inheritance Practice in Manggarai}

The inheritance practice in Manggarai is closely linked to the belief system, the agricultural practice, and the family structure. Regarding its belief system, Manggaraians believe that nonliving beings like lands, houses, and farms have spirits dwelling in them. Moreover, the spirits of ancestors and parents who have passed away are always watching over the living. Rituals are deemed as a way to communicate and make peace with the spirits of non-living beings and of ancestors. Failure to adhere to rituals, including inheritance practice, is deemed an offense towards the spirits.

How inheritance is practiced depends on the village structure. The traditional village structure divides people into villages centered on mbaru gendang (a drum traditional communal house). A mbaru gendang is headed by a tu'a golo (headman) assisted by a tu'a teno(chief of land) and other tu'as. Mbaru gendang is a communal house which is also referred to as a great house in other Asian cultures. Traditionally, the head and the vice head of each clan lived in this house. Today, it is more common for the family of the most senior member of the clan to dwell in mbaru gendang, but it is still considered a communal house instead of a private property (Lon 2015, 129-146).

A mbaru gendang owns the forest, the communal land known as lingko, and every other land in the village. Every clan in the village gets a share of these lands. The clan would subsequently distribute its land to family heirs within the clan, which would then inherit it to the next generation of heirs. The status of an individual in the family and the clan determines whether he would be the deserving heir. Generally, the firstborn son of the clan would get most of the inheritance, followed by the subsequent sons and the sons of the brother clan.

Despite its status as a communal land, lingko is commonly used by certain individuals within the clan. Traditionally, lingko could only be inherited to sons of the clan and must not be traded or inherited to daughters. As time passes and people grow less attached to the clan system, many people who inherit lingko sell their share away. This is especially due to agrarian law introduced by the Indonesian government which only accommodated individual land and not communal land. As a result, lingko which was meant to be a communal land is now officially owned by certain individuals. Today, a lingko land can be sold to individuals outside of the clan as long as tu'a teno is informed. His role is no longer to control, but to oversee the land to ensure its security and to ensure that the buyer would truly be the owner of the land (i.e. it is not sold to other parties or the buyer is not a land agent). However, selling of lingko has become quite an issue in Manggarai causing individuals to be involved in a dispute where multiple parties claim to be the rightful heir to the land.

Besides involving communal properties, inheritance can also involve private properties. People in Manggarai make a clear distinction of inheritance based on their locations: inside the house (ceca mbaté oné mbaru), outside the house (ceca mbaté péang mbaru), and the house itself (mbaru). Some examples of inheritance inside the house are antiques and furniture. Some examples of inheritance outside the house are cattle like buffaloes and horses, farmland, and paddy field. The custom rules that the eldest son of the family (ata ngaso) is the rightful heir to family's inheritance. If for some reasons he is unable to receive the inheritance (e.g. death), the right is passed to his younger brother married through cross-cousin marriage/married a woman from the same clan (tungku). The next person in line is another younger brother (can be married on unmarried) who is deemed capable by the family to carry out all traditional rituals. If the father has many wives, the inheritance is divided according to the time when the properties were acquired i.e. all properties acquired when the father was only married to the first wife would be passed down to the sons from the first wife, and the properties acquired after the father was married to the second wife would be passed down to the second wife's sons. However, in most cases, the second wife and her children are more vulnerable to unfair inheritance rights. 
Inheritance can be passed down while parents are still alive. This usually occurs when the son is getting married. It can be witnessed by the clan members and all the $t u$ ' $a$ s or it can also be held in private only in front of the family members; there is no strict rule on the procession of inheritance endowment. Inheritance can also be passed down when the father is getting old to provide a sense of security to his children once he passes away. Inheritance can also be given after the father has passed away, where the eldest son would gather everyone and divide the inheritance according to the father's will or following the order of men in the house. In general, none of this process is documented in writing. Only in some recent years do some fathers specify their will through a written will. It is generally performed verbally as to involve the spirits of the ancestors and the spirits of the inherited objects. This often leads to legal issues later on due to the absence of certificates of ownership.

Traditionally, women could not get a share in the inheritance, but they could earn a share of wida or widang which is loosely translated to gifts or presents. This is different from inheritance, as wida or widang is associated with parents' sympathy or an expression of love and is not compulsory. Usually, well-to-do families grant wida to the daughters after inheritance for the sons are settled. However, wida is not exactly a gift, as the daughter at the receiving end is still expected to return the favor (it used to be in the form of woven fabric and cattle but now it is common to give cash). This gift can be of a smaller, equal, or higher value than the wida. This process must be known and agreed by the sons. If the daughter is more economically affluent than her father or brothers, it is common for the father to give her a plot of land as wida and she is expected to return the favor in cash of higher amount than the market value of the land. This is done so as to prevent the family from selling the land away and out of the family, especially when they are in dire need of money. However, the term "buying and selling" is always avoided in wida as it supposedly symbolizes father-daughter relationship. Another thing that may happen if the daughter is more affluent than her father or brothers is that if the father and the brothers borrow her money, it will be returned as wida, usually in the form of land. Once she receives such wida the debt is considered paid off, even though it is never explicitly expressed in that way as wida is still deemed as a gift. In other words, she cannot expect her debt to be paid off once she receives a wida. Wida can be gifted before the daughter gets married. Once the groom's family presents bride-wealth to her father and brothers, she will in turn be rewarded wida by her in the form of jewelry, sarong, and other bedroom necessities (Nggoro 2006, 58-59).

\subsection{The Practice of Contemporary Inheritance}

This research explores how families in Manggarai today endow inheritance, especially in association with perception of gender. Inheritance in this case focuses on land and house. The respondents of this study comprise of 179 families, where 92 families lived in villages and 87 families lived in the town center. The respondents were chosen purposefully, whereby all families had daughter(s) (with or without sons) and owned at least a house and a plot of land. Families living in villages tend to have more plots of land than those in town but with a lower market value.

Out of the 179 families, only 8 wives $(<1 \%)$ stated that they had received inheritance (all in the form of land) from their father/brothers. Five of them lived in the village and 3 in town, but there were only 2 women whose fathers were from the city and the rest of their fathers lived in the village. Three women managed to have a share of family land because they did not have any brothers. These women claimed that if they were to have a brother, it was very likely that the inheritance would go to the brother according to the tradition. Three other women were granted land as wida because they had previously lent their parents and brothers money. For the two remaining women, even though they had brothers, their parents chose to also inherit them a small part of the land. 
When our female respondents were asked on their opinion regarding inheritance system in Manggarai, they mostly stated that it was practiced according to the tradition. Those who had received inheritance from their parents felt it was an extraordinary act. Even though some, especially those with brothers, expressed their disappointment and feeling of unfairness upon not receiving inheritance, they felt it was not wise to go against their parents' will especially if they had passed away. Out of the six women who received land as inheritance/wida from their parents, two claimed that the land had been forcefully taken away by their brothers once the parents passed away. For some of these women, the name written on the land certificate passed to them was their husbands' name instead of theirs even though the land was given by their own parents. These women did not find it intriguing as they believed it was common for a man's name to be written on the legal certificate rather than a woman's name. They did not mind as their husbands and themselves were a unit.

Out of the 179 families, 55 families $(30 \%)$ had only daughters and no sons. These families admitted that they had given (or would give) their daughters a share of family inheritance. There were various systems in the distribution of inheritance. Some followed the order of seniority, whereby the eldest daughter would get the most share, but generally there was no clear system as it differed from one family to another. Some of these families' children were not yet married, so the parents had not given them the inheritance. However, all families agreed that all their daughters should get some forms of inheritance or wida. Regarding their house, parents agreed that it would be inherited to the daughter who would take care of them in their old age. Out of the 55 families, 9 families also inherited land to their nephews in addition to their daughters. The reason behind this was because the land was originally inherited from the grandfather and the nephew was the heir of the clan

For the remaining 124 families with both daughters and sons, the system of inheritance was more complex. All respondents agreed that inheritance in the form of a house would not be given to their daughter but only to their son even if the son had the economic capacity to afford his own house. We met one family where the father had passed away and the mother was sick. The mother was cared by the daughter who was economically challenged, while the son migrated out of the island due to his job and would not likely be coming back. However, the family had decided to inherit the house to the son. When asked about the daughter's opinion on this, she admitted that she was upset but she could not do anything against her parents' will and the tradition. She also felt that her brother was greedy as he did not take care of the sickly mother yet expected the house for himself. Regarding inheritance in the form of land, 101 families out of the 124 stated that they would only give them to their sons and not daughters. Only 23 families claimed that they would inherit the family land to both daughters and sons. There were various reasons for not wanting to give their daughters a plot of land as inheritance. The most dominant reason was to follow the tradition. The parents believed their daughter would get a share of her husband's inheritance. The parents also stated that due to limited availability of land, sons would be prioritized over daughters. However, most parents clarified that despite differing inheritance rights, they believed that their daughters and their sons had equal rights to pursue education. In fact, some believed that supporting their daughters to go to school was a comparable act as giving them inheritance. In addition, parents shared that despite giving their sons inheritance, they would prefer to be taken care of by their daughters in their old age. Most parents who gave or would give their daughters a share of inheritance came from well-to-do families. They stated that the main reason of doing so was because the family had a big plot of land enough for both sons and daughters. Some families also believed in equal inheritance rights of their daughters and sons. Some stated that the inheritance was also a form of appreciation for their daughters who would likely take care of them in their sickness and old age. However, all parents also agreed that when their daughters were given wida, they should return the favor in the form of cash, woven fabric, or cattle (pigs, buffaloes, or cows). Eighteen of our female respondents (mothers and daughters) who had received inheritance in the form of 
land shared that they did not mind having their husband's name on the certificate of ownership. Only five respondents felt that it should have been their names written on the certificate instead.

When our female respondents were asked about the significance of inheritance and this tradition, most agreed that this tradition was important economically. Inheritance enabled them to own a land or a house, which were considered valuable properties; hence, helping them economically while allowing them to spend their own money on other necessities such as children's education. Inheritance was also a symbol of parents' relationship with their children and their care for them. The female respondents who were granted inheritance felt valued and cared for by their parents. They also felt that inheritance allowed them to feel confident and equal to their male siblings. They also believed that inheritance gave them more value in the eyes of their husbands as it could contribute to their family property. In other words, our female respondents felt that inheritance empowered them both economically and psychologically.

\subsection{Patriarchy and Selfish as Challenges to Gender Equality}

The practice of patrilineal inheritance in Manggarai has shown that patriarchy is real and is still dominant in today's society. Patriarchal system places men as dominant owners of properties and leaders over women and children. Patriarchy as analyzed by scholars such as Walby (1990) [23][24], had been shown to equate men as the symbol of power while disempowering women. In gender hierarchy, discrimination is often institutional and sacralized and as a result, it is often difficult to challenge as it is often unnoticed and is taken for granted as a part of the culture. The social structure in Manggarai shows a clear gender hierarchy reflected in the inheritance system. Even though people in Manggarai today are aware of gender equality, it is still difficult to practice gender equality in the endowment of inheritance for fear of sanction from spirits and ancestors when this tradition is disregarded.

Patriarchy exists in many forms (Majstorovi and Lassen, eds 2011), that it is always about the relationship of a dominant group to subordinate group, considered inferior. This gender ideology depreciates women, limiting their access to and chances at equal economic, social, cultural, and political opportunities as men. Patriarchy also robs women off a chance to have an autonomy or power as an individual who requires support and justice within the family. This research has shown that patriarchy in the inheritance system has subordinated women, causing women to be "something else is less important than the other thing". Patriarchal ideology encumbers the achievement of a just society for both genders. Gender equality requires a huge transformation, including in cultural areas and rituals considered sacred.

In addition to patriarchy, marginalization of women is exacerbated by dominant individuals, particularly men in power, who lack sympathy towards women. This is often based upon greed and fear of losing power. In the context of this research, a son's greed and unwillingness to share can interfere with parents' wish to endow inheritance for their daughter. In this study, we had observed some cases where the brother forcefully took away his sister's inheritance after his parents passed away. A fair system can fail in the hands of powerful individuals who are materialistic,selfish, and unsympathetic. This suggests that transformation within society does not only depend on changes in the system but also changes in individuals, especially those in power. Arensberg (2017) suggests that social change is possible as long as people are willing to step out of the box and become agents of change in the community. Conversely, a good system cannot work without individuals who are willing to change and innovate. Studies have shown that there is an increasing individualism in many cultures in today's world (Hamamura 2011, 324) (Hamamura, 2012: 3-24). This has also been observed in Manggarai, where people grow less connected to the communal and clan system. The transformation from communal to individual system gives autonomy to families to decide inheritance rights of their family members without consulting the bigger community. Such weakening of communal force is a double-edged sword. While it may champion positive impacts by empowering people to leave 
gender-biased traditions, it marks the loss of social and cultural control. In the context of inheritance in Manggarai, parents who are willing to break away from traditions enable their daughters to have inheritance rights. Not only does this benefit the daughters, parents too can form more meaningful relationships with their children. On the other hand, weakening of social control over inheritance may challenge the legality of said inheritance. When inheritance decision is controlled and agreed by leading roles in the community, everyone in the community must adhere to it. In the past, no individual can challenge the decision of the clan over the heir to the inheritance. However, with the lack of communal involvement, women's inheritance rights can easily be taken away by their own family members. A brother can easily claim his sister's inheritance in the name of tradition after their parents have passed away, as no one else other than the family members would know the parents' decision. In fact, the clan may even support the brother's right over the inheritance according to the tradition.

\section{Conclusion}

This study has discovered that despite changes in people's general perception on women's rights, inheritance remains patrilineal. Many families still exclude their daughters from inheritance rights especially when they have sons. However, changes are seen in families with only daughters: the families are willing to pass down family inheritance to their daughters instead of granting it to their nephews as traditionally practiced. A small minority of family provides inheritance to both daughters and sons, although in some cases, the sons would later forcefully take the family inheritance from their sisters once the parents passed away. This shows that gender equality especially with regards to inheritance rights is not only challenged by the patriarchal system, but also by some individuals' (particularly men's) greed and materialism. Inheritance can affect one's economic, cultural, social, and psychological stability. Economically, inheritance provides valuable assets and allows the receiver to have more disposable income which can be channelled towards other causes such as health and education. Culturally, inheritance is considered prestigious and gives the receiver confidence of his/her position in the family and the community. Socially and psychologically, inheritance strengthens bond between the receiver and his/her parents and ancestors. When women are excluded from the family inheritance system, they are also excluded from these benefits; conversely, giving women inheritance allowing them a chance to become a respected individual in the family and community. In reality, the inheritance culture in Manggarai is still heavily influenced by the persisting patriarchal ideology. Transformation is also difficult, as people in power-men, fathers, leaders in the community - are the same people who will be benefitted by this patrilineal inheritance system. This was further reinforced by the presence of the Catholic Church which also showed a patriarchal system. These people are hiding behind the shield of tradition to justify their greed and unwillingness to be inclusive. Tradition becomes a pretext to allow injustice towards women to continue. This study has signified that marginalization of women in today's society is often rooted in persisting patriarchal practices hiding under the pretext of tradition. Unless there is a radical change in the cultural system coupled with support from various parties in the community, this phenomenon cannot change. Educating people, especially men in power, about gender equality is important for this transformation. Reconstructing old values and ideals that are biased towards women is also necessary. Women themselves need to be active agents of change by voicing injustice they have suffered. For this, women need to be educated and strive for a good occupation in order to have power and value in the society. Economic empowerment of both women and men are also necessary so that they will eventually be independent of inheritance. 


\section{Acknowledgments}

We would like to expres our gratitute to the Indonesia Catholic University of Saint Paul Ruteng for the support and encouragment to us to finish this research.

\section{Reference}

[1] UN WOMEN, "Realizing Women'S Rights To Land," 2013.

[2] UN, "UNAIDS Action Framework :", no. August, 2009.

[3] M. R. Carter and C. B. Barrett, "The economics of poverty traps and persistent poverty: An asset-based approach," J. Dev. Stud., vol. 42, no. 2, pp. 178-199, 2006.

[4] A. Mckay, "Working Paper background paper," no. 100, pp. 1-30, 2009.

[5] E. Cooper, Inheritance and the Intergenerational Transmission of Poverty in Sub-Saharan Africa: Policy Considerations, no. 159. 2012.

[6] A. Whitehead and D. Tsikata, "Policy discourses on women's land rights in sub-Saharan Africa: The implications of the re-turn to the customary," J. Agrar. Chang., vol. 3, no. 1-2, pp. 67-112, 2003.

[7] P. Panda, "Property Ownership \& Inheritance Rights of Women for Social Protection - The South Asia Experience Synthesis," Int. Cent. Res. Women, 2006.

[8] S. Roy, "Empowering women? Inheritance rights, female education and dowry payments in India," J. Dev. Econ., vol. 114, pp. 233-251, 2015.

[9] S. Bhalotra, R. Brulé, and S. Roy, "Women's inheritance rights reform and the preference for sons in India," J. Dev. Econ., 2018.

[10] Y. Hu and J. Scott, "Family and Gender Values in China: Generational, Geographic, and Gender Differences," J. Fam. Issues, vol. 37, no. 9, pp. 1267-1293, 2014.

[11] C. Zhou, X. L. Wang, X. D. Zhou, and T. Hesketh, "Son preference and sex-selective abortion in China: Informing policy options," Int. J. Public Health, vol. 57, no. 3, pp. 459-465, 2012.

[12] S. Butt, "Inheritance in Indonesia ASIA-PACIFIC," no. 12, 2012.

[13] S. Kelly, "Hard-Won Progress and a Long Road Ahead: Women's Rights in the Middle East and North Africa," Women's Rights Middle East North Africa Prog. Amid Resist., pp. 1-21, 2010.

[14] D. Hacker, "The Gendered Dimensions of Inheritance: Empirical Food for Legal Thought," $J$. Empir. Leg. Stud., vol. 7, no. 2, pp. 322-354, 2010.

[15] R. F. Littrell, "Equality , Diversity and Inclusion: An International Journal Article information:," An Int. J., vol. Vol. 32, no. Iss 3, pp. 310-324, 2013.

[16] F. Lon, Yohanes \& Widyawati, "Lingkaran Kekerasan Terhadap Anak Dalam Masyarakat Manggarai," vol. 9, no. 1, pp. 12-20, 2017.

[17] W. F. Lon Yohanes, "Cultural Aspects on Child's Development and Parenting in Manggarai, East Nusa Tenggara, Indonesia," vol. 7, no. 1, pp. 130-139, 2017.

[18] F. Widyawati, Catholics in Manggarai, Flores, Eastern Indonesia. 2018.

[19] M. Erb and and F. Widyawati, "Missionaries and Mining: Conflicts over Development in Eastern Indonesia," in The Mission of Development, BRILL, 2018.

[20] Y. L. Fransiska Widyawati, "Paramita," ParamitaHistorical Stud. J., vol. 29, no. 2, pp. 178-189, 2019.

[21] Y. S. Lon and F. Widyawati, "Cultural Aspects on Child's Development and Parenting in Manggarai, East Nusa Tenggara, Indonesia," Guid. J. Ilmu Pendidikan, Psikologi, Bimbing. dan Konseling, vol. 7, no. 1, Aug. 2017.

[22] Y. Servatius Lon and F. Widyawati, "Humaniora Bride-Wealth: Is There Respect for Women in Manggarai, Eastern Indonesia?," 2018.

[23] S. Walby, "Theorizing Patriarchy - Sylvia Walby.pdf." 1990

[24] S. Walby, "Gender mainstreaming: Productive tensions in theory and practice," Soc. Polit., vol. 12 , no. 3, pp. 321-343, 2005.

[25] T. Hamamura, "Are cultures becoming individualistic? a cross-temporal comparison of individualism-collectivism in the united states and Japan," Personal. Soc. Psychol. Rev., vol. 16, no. 1, pp. 3-24, 2012. 